would be wrong to blame the engineering professors, who appear willing to change, although they contribute to the suspicion growing between science and engineering in Britain. Nor is the government to blame, for it seems fully aware that British engineering should be more innovative and more flexible. The real difficulty is that for industry survival must now depend on making saleable products for the first time, and British industry does not fully understand what skilled engineers could accomplish.

The Finniston report itself provided plenty of evidence to show that British engineers once at work have ahead of them a poor prospect for a career. A few years after formal graduation, and once the two-year period required to become a chartered engineer is completed, the salaries of those still working as engineers for British companies appear to level off. While the statistics are notoriously untrustworthy - many who began as engineers may quickly become salesmen or administrators - industrial companies appear to set little store by the work required of professional and experienced engineers. But especially now, when the new technologies in microelectronics and telecommunications have thrown up almost an embarrassment of devices that might be manufactured and sold profitably, and when one of the most serious problems facing British companies and their competitors is to decide which of these might be made cheaply and sold profitably, there is a greater than ever need of people with a proper engineering education who might help chart a reliable course for the future. What this in turn implies is that British industry must look for a system of higher education in engineering that will produce large numbers of qualified and creative people who will more often be employed in research and development than in the running of plants, production engineering or whatever and, if the engineering professors would reflect on that ideal state of affairs, they would surely recognize that then the status of engineers in Britain would truly be enhanced. Contributing to the health of the economy would automatically win the respect that could not be acquired by a list of research papers an arm long. It might then even be the case that engineering teachers, themselves transformed by industry's expectations of engineering qualifications, would more eagerly take up the funds that the Science and Engineering Research Council is apparently eager to seize back. But another research council, exclusively concerned with engineering research would be at best a red herring.

\section{Economic research?}

\section{Can Congress realize its adage that investment in basic research will aid economic growth?}

The US Congress is now wrestling with a problem common to all the industrial democracies: how to get the most economic benefit out of the nation's investment in research and development. Because the US economy is so decentralized, Congress is attacking the problem with the only central mechanism under its control, the federal research budget worked out each year between the current Administration and Congress. Last December the US Congress, on a sweeping 90 to 0 vote, decided that one way to do this was to set aside one per cent of federal research and development funds (excluding those going to in-house research) for small independently-owned companies employing 500 people or less. These firms have traditionally brought forth many more innovations than the giant US corporations that gobble up most of the federal industry research and development budget and spend most of the private money spent on industrial research in the United States.

The "set-aside"' is meant to do two things: first to establish a federal policy that enhances the role of small businesses in research and development, second to generate more research results that can be turned into commercial activity on the open market. The plan is modelled on a successful programme developed by the National Science Foundation that has enabled small firms to attract private capital, increase employment and, in a few cases, achieve great commercial success.

Other countries are also trying to address this problem. Great
Britain has two smallish programmes, one that sets up "teaching companies", or long-term collaborations between universities and industry, and the CASE programme that works at the student level, placing individual students in companies in such a fashion that their industrial research earns them credit towards their degree. Although having some direct federal programes in priority areas, West Germany relies primarily on tax incentives to stimulate industrial research and development. Small German firms tend to contract with larger ones for the basic research they need to do before a project reaches the commercial stage. All are concerned with the same thing: how to transfer knowledge out of the basic research sector and into the increasingly competitive national and international marketplace.

However, representatives of US universities have objected strongly to the bill, arguing that while the objectives are worthy, the mechanism of "set-asides" will shrink the share of the federal research budget that goes to the universities. They would not care if Congress was in a spending mood and simply authorized more funds for small research and development firms. But everyone in Washington is tight-fisted these days. The Administration could not have supported the legislation, as it does now, if it proposed to add more money to the budget. The legislation proposes to take the money from the existing budget, and so spokesmen for the universities have been crying, "Why us?", although the Senate version, which the House will probably also pass, limits the "raid" on basic research funds to one per cent of the basic research funds of any agency. The objections from university spokesman are loud and clear. However, there have been fewer objections from the contractors and applied researchers who now get the remainder of the federal research and development budget, some of whose funds will be used to make up the balance of the new programme.

University scientists have reason to be concerned about protecting their share of the federal research and development pie from encroachments. But the objections to this tiny set-aside which is likely to be $\$ 300$ million in all, of which a small part would come from basic research - have been strident even at a time when the workers at General Motors accepted voluntary wage and benefit cuts to help bail out that ailing enterprise. If the most entrenched workmen's unions in the United States can make concessions to remedy the US economic troubles, cannot the better paid, supposedly more high-minded scientists?

In objecting to the legislation, spokesmen for universities and for basic research have been anxious to preserve their own turf at the expense of everyone else's. Senator Warren Rudman, the prime mover behind the bill, is fond of quoting a prominent scientist at Massachusetts General Hospital stating he was not concerned about whether small businesses got more research and development, only about whether "one" of his investigators lost a grant because of it. What is missing here is any perspective from the scientists that they are part of any larger effort. Remember the old idea that the United States should invest in basic research for the sake of economic growth, productivity and the creation of jobs?

The new bills, therefore, put the US university science community squarely on the spot. Thirty-seven years ago, Vannevar Bush and his colleagues persuaded the US government to sponsor basic research in the universities, and required that it have special, protected status, its own programmes and agencies, because, as Bush wrote, "Basic research leads to new knowledge. It creates scientific capital. It creates the fund from which the practical applications of knowledge must be drawn"'.

Small firms are also part of the "fund" from which practical applications are drawn, both those which do basic research and those which do not. If the university spokesmen are truly concerned about national productivity, creating new inventions, and economic health - as they have said they were in selling their own budget requests to Congress in the past - they should support any measures that further that goal. At least they should offer constructive alternatives. But they do the image of science - and the US economy - no good by limiting their comment to paranoic fears that their particular sector will be hurt. 